する目的のるので, 梖悍の端末の動きを 1 回転 100 洔 間で回転する円筒に卷いた記録紙に拡大記録するあの である。伸び $0.1 \mathrm{~mm}$ が記録゙紙、たK $5 \mathrm{~mm}$ に、時間軸 は 1 時間が 3・15 mm 亿表わされる。

\section{2. デケード式伸測定器}

これは試験片の伸びを精密に測定する目的のるので ある. 試験片の両側各個に標点距離の両端に固定した クランパーから取付アームをそれぞれ 2本ずつを怩外 に引出して, 差倒変圧器のケースと内部のアマチュア

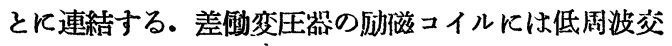
流を流し，出カコイルは逆極性に接続し，それらの中 心を通つてアマチュアが仲ひに從つて移動寸る.それ でアマチュアが快位置から移動すると, 出カコイル に誘起される䉓压を雨侧の差扸变圧器のものを合計し て、ナなわち試験片の微小な曲がりを平均した作び

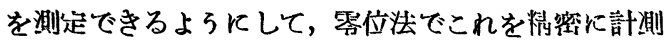
する. それには測运箱の中にある伸ひの $1 \mathrm{~mm}, 0.1 \mathrm{~mm}$ 飛ひに対応寸る切換抵抗と，伸ひの $0.001 \mathrm{~mm}$ まで放

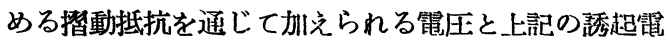
圧とが平衙するよらに，これらの抵抗を加㳦して帆心 を則定するのである.この平衡位㯰の判別示特斺の平 衡検出增幅回路によつて行ねれ尽。

このよろに切换抵抗，替野抵抗が十進法に目绕られ ているので，使用上極めて便利であつて，しかも柋度 $0.5 \mu ，$ 精度士2.5 $\mu$ が保証されている。

\section{3. クリープ試験機 C-II 型}

最近前記の I 型に考干の改㢃を加えて I 型を造つて いる.これの本体は第 5 図のと括りで，制御パネルは

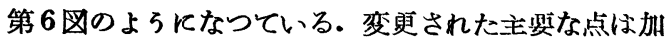
熱系統の自偪制御方式であつ'て, 多数のリレーの代り イブリジの不平衡電圧を增湢して可逆モータを㑬か せて，加熱回路の直列抵抗の括入短络を行らものであ
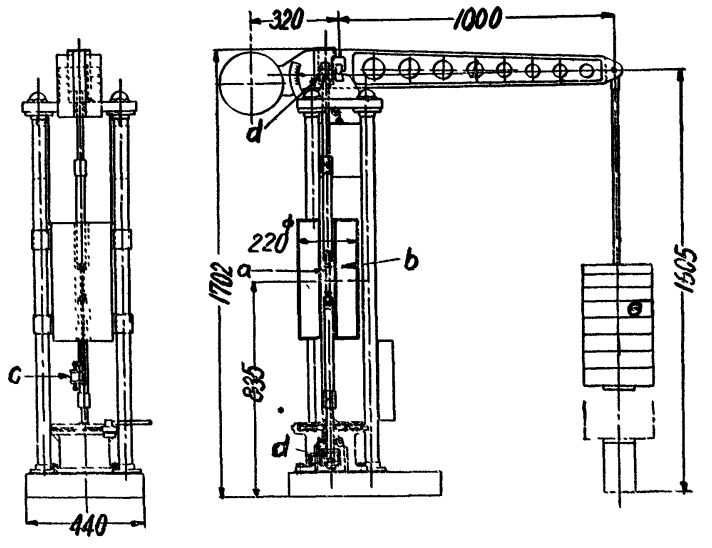

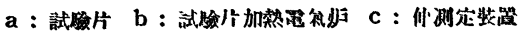

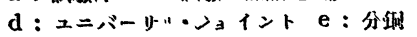

第 5 图クリーブ試験機 $\mathrm{C}-11$ 型林体

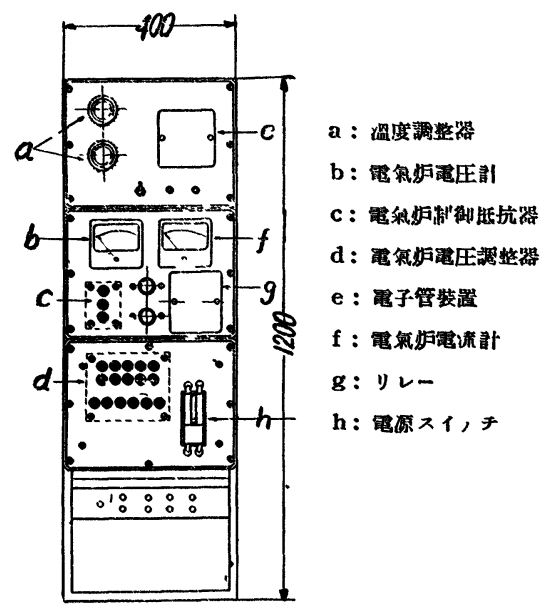

第 6 因 クリープ試験僟C-I型制御パネル

る.この結果は制御パネルを見てもわかるよらと，非 常に簡粆になり，しかも作用は確実であるといらこと くなつた。

\title{
丸棒鋼材連続検查用島津嵫粉探傷機 SHR-160型についで
}

\section{直 壁 英 樹**}

\section{1. 主要な用途}

本磁粉探傷機は，特殊鋼の丸棒鋼材の㾟を連続的に 検査するために製作された超大型磁粉探傷機であつて， つぎのごとき性能を有している。

*原俵受付 昭和29年3月 8 日

**练计会社島聿製作所 研究部
被検查物特殊鋼丸棒鋼材，長さ 1 4 $\mathrm{m}$, 直経 $30 \sim 90 \mathrm{~mm}$

検査能力 1 日約 30 順

な扣操作人員は2人程度で充分・㐫る。

\section{2. 特長}

1. 安全な保護装置, 指示装置があるから, 使用が簡 


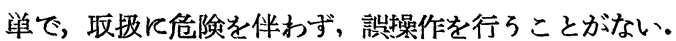

2. 商用周波の 3 相交流䇫源 220 ボルトを用いてい るので，汪とんど全ての場所に設置でき，保全が容易 である.

3. 操作が小人数で，进速に，能菜よくできる。

4. 磁化電流は强大で，任意にその佔を調節するこ そができ，しかむ操作中に正確にその值を読むことが できる.

5. 本㙨は，生䒚工程中反品筫管理の目的で検查で きるよらに設計されているので，連続使用ができる。

6. 常洔シャワーに上り試料以梌查㖡を敞乍与る逨 続法によつているので，各程の鎆仏の梌査ができる。

7. 椿造が堅固であるので，柆大，垂量物の連続梌 查が谷易に扣こなえる。

8. 多年の経踰と特殊な技術に上り処理された白色

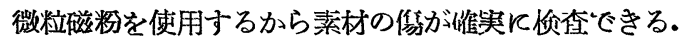

\section{3. 構造}

本機は第 1 四の配置図のように，つぎの各部分から なつている。
ルトまで調節可能であつて，試料の大きさと応じて， 最大磁化䉓流を 2500 アンペフに保ちらるようとなつ ている。磁化電流は操作盤上の押ボタンを押寸か，ま たは着磁装置のリミノトスイノチにより自動的に限時 装置, 補助継電器, 電磁開閉器によつて通電され, 試 料儿低電圧大電流が短時間(最大 2 秒まで調節可能)流 れるようとなつている.

（2）着磁第 2 四に置すよ5K，試料を2つ の接触板間に保持するために固定接触頭と可動接触頭 とが装置されて特り，固定接触䌿は試料の長さと応じ て適当な位.置にボルトで締めつける. 可動接触嗔は操 作配電盤のスイノチにより䉓動機で前進, 後退せしめ ることができる.ささらにスプリングと固定接触頭カバ 一内にあるリミノトスイ,チの作用とよつて任意の压 力で試料を保持し、自動的に通䉓できるよろとなつて いる. 固定接触頭の可動距離は $13 \mathrm{~m}$, 可動接触頭の

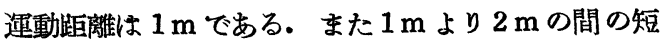
い試料の㭘査には，両接触䫓に補長韻をとりつけるだ けで簡単に叔こなえる。

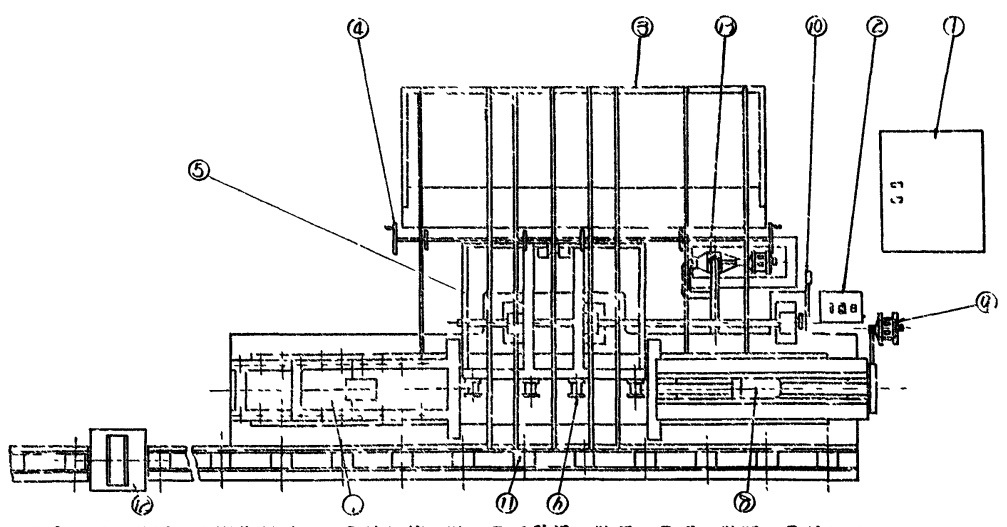

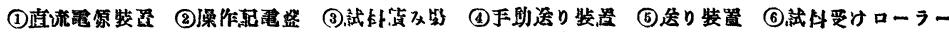

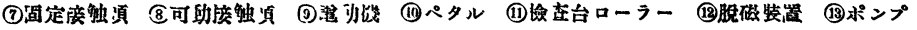
第1図配是圆

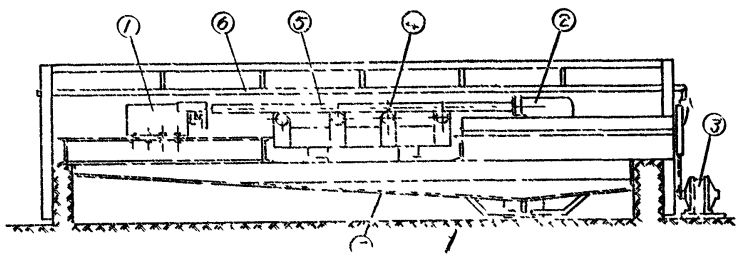

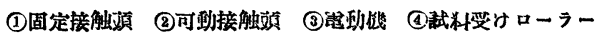
(5)試料 6シムワー管 (7)㮝查波慒

第 2 図着磁装咱略図

（1）值流望源装置，（2）着磁装置，（3）試料送り装

置，（4）磁粉油散布装置，（5）脱磁装置

（1）直流電源装置 本機の磁化用直流電流は，3 相交流 220 ボルトより, 変圧器を経て, セレン整流器 により半收整流してえられる。变圧器の 2 次僛電圧は 電圧調整用切尖スインチにより，4.6 ボルトより 12 ボ
（3）試料送リ装異 試料置 場に積まれた試料ば, 手動送り ハンドルで一本ずつ傾斜したレ ールの上を転下して試料保持 装置の受けにはまりこみ，その 場所で可動接触頭により着磁さ れる。そのため受けは電気的に 充分絶縁されて扣り，着磁後は ペタルとレバーにより簡単に試 料をレールに沿つて枟下せしめ， 㭘查台几送りらるようになつて いる. 検査はレーラー上で試料 を送りながら括こなら。

（4）磁物油散布装置 試料 保持装置の下部には検查夜䠉藏タンクが装置してあり， ポンプイよりたえず㭘査庱（石油）中の磁粉を適当な 混和状態にあるようと覮找し，また一方では着磁時常 時試料の寸ぐ、加ら雨状に均一飞椧査液が散布される よろに調節可能な特珠シャワー装置が辇備されている ので, 残留磁気法で扣こなえない試料でる連続法によ つて検查することができる。

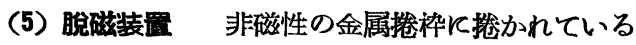
脱磁コイルは，ローラー検查台の端にとりつけられ， 検査が終了した試料をローラーによつてコイル中を通 せば,リミノトスイノチにより自動的に通電し, 脱磁 できるよろになつている。

\section{4. 各装置の寸法}

（1）直流電源菱置 $1.2 \times 1.0 \times 1.9 \mathrm{~m}$ 


\section{LUMINEX 島津螢光探傷機 II U 型 ${ }^{*}$}

\section{LUMINEX の用途}

磁性体の欠晸検査には従来から磁粉探傷機が使用せ られ，各方面ですぐれた検查凑績があげられて特り， 鳥津磁粉探賃機がこの探傷に最適のるのとして，鉄鋼， 航空機，ベアリング，自動車工業関係に続々採用され ている.

一方非磁性体の久晸検査とついては，今日まで簡単 て適確な検査法がなく，やむをえず不完全な内闪眼娭查 によつていたような状態である。先般新製品として発 売した LUMINEXはこの問題をすべて解决し,非磁性 体の表面賃検查を確実に能率よく扢こならことができ る画期的な装置である。しかも，この表面傷の検査は 肉腿梌查では見えないーヤークラング波学現象も確 実に探倠することができる装置である。 LUMINEX は非磁性体の銅，黃銅，アルミニウム合金，ステンレ ススチールその他の金属はもちろん，陶磁器，合成樹 脂などの表面偒検查にも使用でき，非常に広い利用分 野をるつている。

今回完成されたI U型は特に重量物の検查をる考慮 に入れ，大量生產向きの工場に適応した構造と樣式と をもつたもので，操作はより簡単，迅速におこならこ とができる。

\section{LUMINEX による㨲傷法}

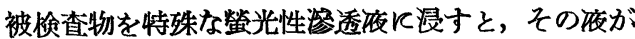
ひびわれ，細孔などの表面㰾内部に遪透する。この被 㭘查物を現像液中に浸けた後, 引上げて乾燥する。こ の処理によつて傷内部の透洨が表面の現像剤に吸着 される.さらに，これを水銀灯で照射すると，現像剤 に吸着された螢光性答透夜が明膫な螢光を発し，傷の 形状，大きさなどを検査することができる。

\section{LUMINEX IIU 型の構造}

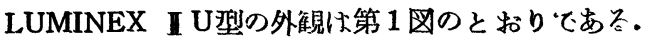
本䒰置一式により次のような操作を抏こならことが できる。

唀 (Penetration), 排液 (Draining),
中 條 鎬 一**

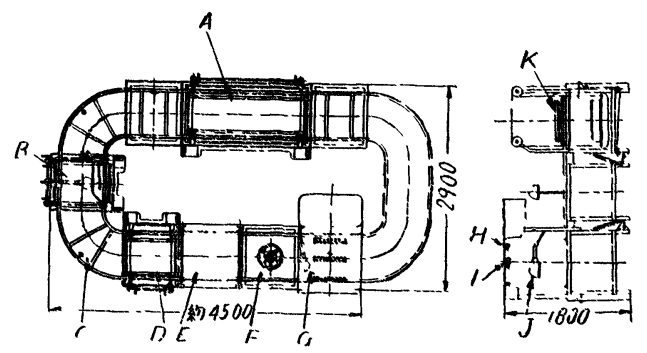
A : PENETRANT

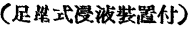 加熱器
最离依度 $30^{\circ} \mathrm{C}$ 自動温度話節器付 電原 A.C. $100 \mathrm{~V}$
B : RINSE

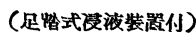
BI.ACK -LIGHT 份敖能力 $125 \mathrm{~W}$

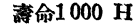
電综單相 A.C. $100 \mathrm{~V}$
C : DRAIN D : WET DEVELOPER E : DRIER

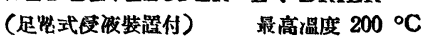 自動湓度調節器付 隔則溫度註付 電棵 毠相 A.C. $100 \mathrm{~V}$

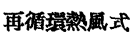

F : COOLER G : INSPECTION STATION 添瓜展

風量 $50 \mathrm{~m}^{3} / 55 \mathrm{~min}$

- 電愿 㗊相 A.C. $100 \mathrm{~V}$

H : 3 BLACK-LIGHT I : 白㻑kJ J : BLACK-LIGHT

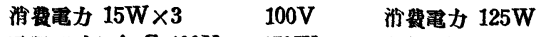
電愿 單相 A.C. $100 \mathrm{~V} 150 \mathrm{~W}$ 㗕命 $100 \mathrm{H}$

$\mathrm{K}:$ 遇般事

電原挐神 A.C. $100 \mathrm{~V}$

第 1 図 LUMINEX 島津监光探鹪機 I U 型の外钼

洗佟 (Rinsing)，現像 (Developing), 乾燥 (Dry), 冷却 (Cooling), 検查 (Inspection) 各装置の構造はつぎのと抢りである。

（1）程透液タンク まず被検查物をこのタンクK

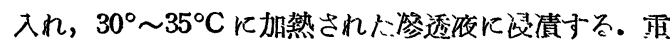

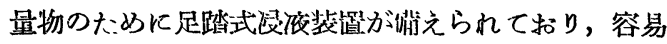

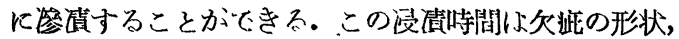

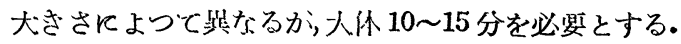

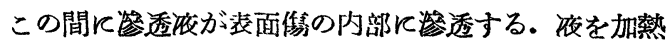

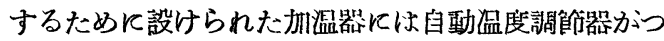
いている。また小さい被㭘查物を多量に処理するため K，金属製バスケ，トが用意されている。

\footnotetext{
* 原稿受付 昭和29年 3月 8 日

**滕式会融岛津繁作所研究部
} 